\title{
FORMA LITERÁRIA E CONTEÚDO SOCIAL: UMA REPRESENTAÇÃO EM NÃO VERÁS PAÍS NENHUM
}

\section{Luciana Novais dos Santos *}

Resumo:Trabalhar o romance aqui em discussão não é tarefa fácil, principalmente quando a leitura é feita nos dias de hoje e percebemos que grande parte desta representação alude a um período da história do Brasil que provoca muitos estudos: o golpe militar de 64 . À medida que lemos a obra, parece que encontramos uma parte dessa nossa realidade histórica representada em uma forma romanesca de há 24 anos.

Uma forma tão antiga de se abordar no tecido metafórico do texto literário aspectos relacionados à sociologia, à realidade que nos circunda, nos faz construir este ensaio, cuja discussão é relacionada como a forma literária, muitas vezes presa a modelos estéticos, a noções de gênero, representa a noção de sociedade e seus vários complexos e paradoxos configurados na imagem do personagem Souza, nosso sujeito problemático, herói degradado, sujeito pós-moderno.

Baseados em Candido (1965), formulamos hipóteses acerca da representatividade de aspectos históricos na forma literária. A literatura, segundo este crítico, sempre foi uma espécie de 'lugar' onde realidades podem adquirir outras conotações, servindo como equilíbrio intelectual à medida que não discutimos temas de sociologia somente em tratados de sociologia ou similares, mas através da ficcionalização do discurso.

Palavras-chave: representação literária; sociedade; forma literária

Ao tomar como corpus de análise o romance Não verás país nenhum, ${ }^{1}$ de Ignácio de Loyola Brandão, duas perspectivas de análise parecem se abrir. A primeira refere-se aos aspectos sociais da obra; a segunda está direcionada à questão do sujeito pós-moderno.

O fato mais instigante que nos levou a esta análise foi a forma com que Brandão trabalhou o comportamento dos indivíduos de uma nação, antecipando, na ficção, prováveis consequiências de uma pós-

* Mestranda em Literatura Brasileira no Programa de Pós-Graduação em Letras e Lingüística da Universidade Federal de Alagoas.

1 De agora em diante utilizaremos a sigla NVPN para o título do romance. 
modernidade experienciada pelos humanos de nossa época e cujas bases, em princípio, já surgiam em ruínas como "um retorno ao antigo, travestido de progresso"2.

O objetivo deste ensaio é analisar a forma como Ignácio de Loyola Brandão aborda toda uma problemática nascida nos estratos sociais, culturais, políticos, econômicos e religiosos da sociedade que representa na obra. Defendemos a tese que a representação do sujeito problemático de um corpus sociocultural na obra em análise caracteriza uma das preocupações dos sujeitos de todos os tempos, mais especificamente aqueles que reorganizam os mundos em seus devaneios literários sem que essa característica empobreça a qualidade do texto que representa, que é um objeto simbólico e material das culturas letradas e não ágrafas.

O corpus escolhido apresenta em seu interior dadas situações que em princípio poderiam nos remeter a um estado caótico de coisas, a uma espécie de desordem, a uma natureza de estilhaçamento e fragmentação dos sujeitos e do mundo em que eles se inserem, a ponto de provocar várias reações no leitor. Esta possibilidade só é possível porque História e Arte estão unidas em forma e em conteúdo.

Trazemos, então, o posicionamento de Candido (1965) para iluminar a nossa análise, levando em consideração a afirmação feita por ele, referindo-se ao contexto que envolve uma narrativa de que "o externo (no caso, o social) importa, não como causa, nem como significado, mas como elemento que desempenha um certo papel na constituição da estrutura, tornando-se, portanto interno". ${ }^{3}$ Podemos assim entender que o contexto social, a vivência que o autor tem do seu mundo, é transportado e redimensionado no texto literário, sendo moldado através da forma, através da estética no romance, e uma das maneiras como esse fato se dá é compreensível através do que Magalhães afirma sobre a expressão da Arte relacionada à História, a partir do momento em que aquela passa a "refletir o ser social sobre sua própria existência", sendo que "não é a história porque o autor

2 POLZONOFF Jr, Paulo. Pós-modernismo: nascimento e morte. 2004.

3 CANDIDO, Antonio. Literatura e sociedade: estudos de teoria e história literária. São Paulo: Editora Nacional, 1965. p. 4. 
resolveu contar o seu tempo, mas porque ele reflete sobre o seu tempo e as possibilidades de ultrapassá-lo". 4

Podemos entender esta relação entre História e Arte Literária como duas formas de escrita que não podem estar separadas, principalmente em meio à pós-modernidade, as quais se concentram no que há em comum e não em suas diferenças, assim como nos diz Hutcheon:

Entretanto, é essa mesma separação entre literário e o histórico que hoje se contesta na teoria e na arte pósmodernas, e as recentes leituras críticas da história e da ficção têm-se concentrado mais naquilo que as duas formas de escrita têm em comum do que em suas diferenças. Considera-se que as duas obtêm suas forças a partir da verossimilhança, mais do que a partir de qualquer verdade objetiva; as duas são identificadas como construtos lingüísticos, altamente convencionalizadas em suas formas narrativas, e nada transparentes em termos de linguagem ou de estrutura; parecem ser igualmente intertextuais, desenvolvendo os textos do passado com sua própria textualidade complexa. ${ }^{5}$

Ao voltar o nosso olhar para o romance ignaciano, é possível percebermos a presença de uma parcela da história do país nele representada. Trata-se de um romance escrito durante o final da década de 70, vindo a público em 1981, momento em que o Brasil vivia os últimos anos do regime ditatorial implantado em 1964 e o movimento cultural da pós-modernidade se iniciava. Entretanto, o homem em sua natureza interior passava por indecisões quanto ao futuro, o que esperar dele, tendo o olhar voltado para o passado; nesse momento pós-moderno, o tempo adquire uma outra conotação, importando para os personagens mais a velocidade deste fator que as próprias ações transcorridas nele, como podemos observar no trecho

4 MAGAlHÃES, Belmira. História da representação literária: um caminho percorrido. Revista Brasileira de Literatura Comparada. Maceió, n. 6, Ufal, p. 70, 2002.

5 HUTCHEON, Linda. Poética do pós-modernismo: história, teoria, ficção. Trad. Ricardo Cruz. Rio de Janeiro: Imago, 1991, p. 141. 
da obra: "O caminhão descarrega refrigerantes factícios no bar. Portanto um mês se passou. Durante as festas o tempo voa. Besteira, o que me interessa a corrida do tempo? Não existe nada a fazer com ele. Que me importa a velocidade se já não tenho uso para minha vida. Quem tem?". ${ }^{6}$

Considerando o presente como conseqüência do passado, o narrador constrói um futuro de fracassos, de desilusões. Para tanto, Brandão produziu um romance em que pôde explorar com grande presteza o tempo da narrativa, provando assim a sua importância, pois, como diz Nunes, "o tempo é um elemento da narrativa tanto quanto um personagem o é". ${ }^{7}$ Esta importância se destaca tanto no âmbito do discurso quanto no da história, elevando a sua relação com a forma ficcional, pois não podemos esquecer o tempo como uma das características que definem a pós-modernidade, sendo valorado ou não pela sociedade.

Como temos falado sobre a importância da relação entre vida social e vida artística, interessa-nos agora apontar fatores que levam o romance ignaciano à tendência da reflexão social a partir de uma determinada época. Nesse caso estamos no momento final de ditadura militar, de uma vivência sob a estufa da repressão, em que o povo começa a tomar consciência acerca da redemocratização marcada pelas Diretas Já. O narrador aborda esse tema constituindo um personagem que experiencia conflitos como perseguição, autonomia, perdas, repressão mantida pela organização de um Esquema, dotado de militecnos e civiltares, mantido pelo governo para o controle dos cidadãos em geral. É possível entendermos que toda essa organização pode ser vista como uma espécie de colagem do cotidiano social vivenciado durante, especificamente, a década de 70 , no qual o narrador já anuncia a fragmentação do hømem rendido à velocidade do tempo na década seguinte.

Importa à análise literária a influência que o meio social causa na formação do romance, como já nos afirma Candido, sobre o

6 BRȦNDÃO, Ignácio de Loyola. Não verás país nenhum. 23. ed. São Paulo: Global, 2000. p. 18

7 NUNES, Benedito. O tempo na narrativa. 2. ed. São Paulo: Ática, 2000, p. 14. 
crescimento e integração da vida artística com a vida social, mantendo, portanto, uma forte ligação entre o artista, a obra e o público-leitor. Essa atitude só é possível a partir do momento em que o escritor convive com os mesmos conflitos de toda a população, quando esses tornam-se perceptíveis e sensíveis ao autor, que os transporta para a materialidade do texto através do narrador, o qual, de forma fictícia, se aproxima do leitor.

Em NVPN podemos encontrar este relacionamento expresso em pequenos diálogos entre o narrador e a personagem Souza, como vemos no exemplo a seguir:

Quer mais tempo? Quanto quiser. Disse que o tempo esgotou, todavia não sei de nada. Só não admito que você morra antes de me dar a resposta. Podemos fazer uma coisa. Se responder, não morre. Está bem assim? Então espero. Quem espera? Que resposta você quer? Quem é você? Quem é? ${ }^{8}$

Poderíamos até considerá-lo um monólogo interior, no entanto o vemos como um diálogo entre narrador e personagem, até mesmo pela proposta "Podemos fazer uma coisa". Entretanto, manter uma relação autor, obra e público causa um efeito diferenciado quanto ao direcionamento da arte literária, de acordo com o que diz Candido sobre a comunicação artística: "a atividade do artista estimula a diferenciação de grupos; a criação de obras modifica os recursos de comunicação expressiva; as obras delimitam e organizam o público". Candido nos leva a entender a essencial relação entre arte e sociedade, e provavelmente um novo conceito de análise literária que fluirá no imbricamento de forma e conteúdo.

Para iniciar nossas considerações, preferimos determinar o momento histórico que foi cenário para a elaboração de NVPN, no qual o caos se faz presente tanto nos aspectos físicos do ambiente quanto no ser do indivíduo, e também acrescentamos a condição em que a arte era mantida no determinado momento da história política e

\footnotetext{
8 NVPN p. 344.

9 CANDIDO, Antonio. 1965. p. 28.
} 
cultural desse país. Neste caso, temos um autor que participou ativamente do momento da ditadura política, sendo o seu romance Zero (1975) censurado pelo governo através do Ato Institucional de número 5 (AI-5), implantado em 1968.

Brandão formou um ciclo para expressar o horror da ditadura militar com os romances Bebel que a cidade comeu (1968), Zero (1975), Cadeiras Proibidas (1976) e Não verás país nenhum (1981), declarando o fechamento desse ciclo através da derrota, em parte, das suas personagens pelas circunstâncias do mundo e da sociedade, revelando aquilo que é possível ao ser social, como se percebe através de sua fala quando, em entrevista aos Cadernos de Literatura Brasileira (2001), ao perguntarem se a população estava chegando ao mundo referido em NVPN, se seria possível realmente viver aquela utopia negativa, ele responde:

Corre. Está tudo aí: os congestionamentos infernais, a falta de chuva e o conseqüente racionamento de água, o corte de energia, a devastação da Amazônia. Quando eu terminei o Não verás, me perguntei por que eu tinha escrito aquele livro. Hoje eu pergunto por que as pessoas continuam lendo o Não verás. Ele vai fazer 20 anos e continua aí. ${ }^{10}$

Trata-se de um romance que de certa forma completou um ciclo político juntamente a Zero. Acreditamos que NVPN não pode ser classificado apenas como um romance do gênero ficção científica, apesar de carregar em si uma linguagem e um mundo totalmente imaginários, mas podemos perceber nele um poder de antecipação dos fatos da atualidade, a exemplo da desvalorização do ser, da luta pela sobrevivência, da fragmentação do sujeito. O romance também é marcado pela atualização de temas, como bem afirma Hohlfeldt: "[...] aquilo que incomodava antes, talvez porque fosse, justamente, algo original, hoje se encontra em harmonia com nossa percepção. Significativa e infelizmente, o texto se atualizou não apenas

10 BRANDÃO, Ignácio de Loyola. Cadernos de Literatura Brasileira. Instituto Moreira Salles. N. 11, Junho, 2001. p. 53. 
estilisticamente mas também em relação a seu conteúdo". 11 Se pensarmos na dialética de que a obra literária é produto/manifestação de um sujeito que trabalha a sua realidade empírica, podemos afirmar que a obra em pauta tende a representar determinadas condições da sociedade no momento de sua composição.

O público também influencia a obra literária, formando um conjunto com o autor e a obra, já que ele também participa na constituição do texto influenciando a sociedade. O romance nasce a partir da experiência coletiva da população e retorna para ela com todo um adorno e uma magia da estética literária que, muitas vezes, transcende a representação social, mas nem todos estão atentos à percepção dos problemas, principalmente os de cunho ideológico e dos valores culturais. Conforme pensamento de Candido, "A sociedade, com efeito, traça normas por vezes tirânicas para o amador de arte, e muito do que julgamos reação espontânea da nossa sensibilidade é, de fato, conformidade automática aos padrões". ${ }^{12}$

Ressaltamos aqui o valor específico que a arte literária tem em si, juntamente com a interação autor-obra-público, a de transformar a realidade em ficção, de forma ilusória, através do fator estético que reformula no texto as ações e os sentimentos dos seres. Até mesmo as necessidades humanas passam a ter uma forma poética através de manifestações altamente estetizadas.

É importante observar, porém, o posicionamento do autor frente aos fatores históricos, tendo na obra o resultado das suas reflexões no que concerne à forma e ao conteúdo, pois já que sabemos que os estudos feitos acerca da obra literária sempre "procuravam mostrar que o valor e o significado de uma obra dependiam dela exprimir ou não certo aspecto da realidade, e que este aspecto constituía o que ele tinha de essencial". ${ }^{13}$ Para tanto, faz-se necessária a integração das categorias literárias com os aspectos sociais e estarmos sempre atentos para o fato de que o escritor tem a sua

11 HOHLFELDT, Antonio. O verbo violentou o muro. Fiç̧ão científica nos anos 70: o caso Ignácio de Loyola Brandão. in: Cadernos de Literatura Brasileira. Instituto Moreira Salles. n. 11, junho, 2001. p.112. 
própria visão da realidade, embora seja livre para construir uma narrativa sem explicitar a sua opinião a respeito do que está sendo escrito.

Temos então um dos fatores que movem o escritor diante da sociedade e do seu relacionamento com a representação literária referentes à função que a obra criada tem sobre o leitor e sobre quem efetua tal representação. Assim vemos NVPN como a transcendência da realidade trazida pelo escritor, na qual o que se mantém é o fato da forma como fora narrado, e não apenas o seu olhar frente aos problemas da sociedade. Todavia, tomando a arte como a mais elevada expressão humana, podemos dizer que Brandão construiu assim esta narrativa, buscando nela refletir as relações entre os indivíduos e o gênero humano. Há, no entanto, uma exaltação da história em si, quando percebemos e reconhecemos que é tida como prioridade na produção artística a fim de tornar-se uma crítica ao real, ou seja, verificando o que está internamente no texto literário.

Brandão é considerado por Silverman ${ }^{14}$ como o autor que "buscou refletir a realidade com uma mistura cativante de concisão jornalística, prosa neonaturalista, realismo mágico e fábula contemporânea". Especificamente no romance NVPN, cuja temática sugere uma leitura crítica dos problemas e do caos vivenciado na metrópole São Paulo. Através do seu estilo escritural percebemos uma mesclagem entre o trágico e o cômico, o real e a fantasia, o presente e o passado; deparamos também com uma visão futurista do Brasil, ao descrever o centro urbano caótico, a subcultura satirizada de forma irônica.

Há ainda aqueles que, como Wilson Martins, ${ }^{15}$ encontram na escrita de Brandão uma temática depressiva que impede o prazer do texto, ao descrever os horrores da destruição do ambiente natural. Entretanto, ele escreve para o nosso tempo, com excessos imaginários, mas também

14 SILVERMAN, Malcolm. Moderna ficção brasileira. Trad. João Guilherme Linke. Ensaios. São Paulo: Civilização Brasileira, 1982. p. 209.

15 Apud HOHLFELDT, Antonio. O verbo violentou o muro. Fiç̧ão científica nos anos 70: o caso Ignácio de Loyola Brandão. in: Cadernos de Literatura Brasileira. Instituto Moreira Salles. n. 11, junho, p.112, 2001. 
reflexões das atitudes do homem (o protagonista Souza) que busca a sua identidade, representando a humanidade, mais precisamente, durante e após o período da ditadura militar. Buscamos na História alguns fatos que Brandão representou tão bem no contexto literário.

Antes mesmo de situarmos a condição do romance NVPN na contemporaneidade, retomemos o caminho percorrido da Literatura Brasileira, em que o nacionalismo esteve sempre presente. Desde o Arcadismo essa temática tem sido abordada pelos grandes escritores. E não seria diferente na pós-modernidade, mesmo que seja de forma agressiva aos leitores; todavia, busca-se a inspiração na realidade mais próxima, a vivenciada por uma nação que até pouco tempo esteve sob o domínio dos colonizadores. A presença dessa realidade verificou-se e verifica-se nos romances, no teatro e na poesia, no ensaio, na música e nas artes plásticas.

Diante da censura política restritiva promovida pelo movimento político de repressão, as formas de expressão artística encontram como alternativa apenas dois caminhos: ora o silêncio, ora a escrita paródica, irônica e lingüisticamente radical, a partir do início da década de 20 . Os artistas, preocupados com a linguagem, pensaram em promover uma quebra de tabus implantados pela sociedade. Organizaram a Semana de Arte Moderna em 1922, iniciando assim o movimento literário Modernista. Com um dinamismo empenhado em renovar não só a arte literária, mas também a música e as artes plásticas, segundo Candido (1965). Na década seguinte, 1930, a predominância foi para a figura do sertanejo, para o regionalismo, tendo como principal enfoque o homem do campo e os seus desafios diante do desejo de se libertar da estrutura latifundiária, e das demais crises do campo, durante dois decênios em que houve a construção de uma literatura contestável, mas válida. Porém, “A partir de 1940, mais ou menos, assistiremos, ao lado disso, a um certo repúdio do local, reputado apenas pitoresco e extraliterário; e um novo anseio generalizador, procurando fazer da expressão literária um problema de inteligência formal e de pesquisa interior", ${ }^{16}$ exigindo um direcionamento maior em relação à forma em detrimento do conteúdo, e a sociologia começa a aparecer também como "pesquisa objetiva da

16 CANDIDO, Antonio. 1965. p. 151. 
realidade presente", ${ }^{17}$ e não mais como ponto de vista, como acontecia antes.

Dessa forma, como afirma Candido, "A posição politicamente radical de vários desses autores fazia-os procurar soluções antiacadêmicas e acolher os modos populares; mas ao mesmo tempo os tornava mais conscientes da sua contribuição ideológica e menos conscientes daquilo que na verdade traziam como renovação formal", ${ }^{18}$ fazendo-nos, assim, voltar para a realidade na qual se encontra NVPN, em uma condição de continuidade política, denunciando certas atitudes e refletindo sobre o momento da sociedade atual.

Vale salientar que a situação atual do romance no Brasil está mais voltada a uma função de mero produto mercadológico, dentro da indústria de consumo capitalista, e isso ocorre devido à modernização da tecnologia, especificamente de produtos industriais da mass media. Apesar de tudo, Santiago (1989) assegura que é a subjetividade autoral que faz a diferença entre os textos literários e que "o romance surge como conseqüência de uma busca de autoconhecimento da subjetividade racional". ${ }^{19}$

Encontramos, na criação literária, muitos aspectos relacionados com a vida social, principalmente no discurso cotidiano representado através da arte. Pensando assim, consideramos que em NVPN encontramos aquilo que podemos chamar de "investigação da função política das obras e dos autores com intuito ideológico marcado", ${ }^{20}$ pensamento que se coaduna com o que pensa Barbosa, quando sobre essa questão diz que "Neste sentido, o que se põe em xeque é não a realidade como matéria da literatura, mas a maneira de articulá-las no espaço da linguagem que é o espaço/tempo do texto". ${ }^{21}$

Ibid., p. 157.

18 Id. A educação pela noite e outros ensaios. 3 ed. São Paulo: Ática, 2000. p. 205.

19 SANTIAGO, Silviano. Nas malhas da letra. Ensaios. São Paulo: Companhia das Letras, 1989. p. 30.

20 CANDIDO, op.cit., p.12.

21 BARBOSA, João Alexandre. Modernidade do romance. In. FILHO, Domício Proença. (Org). O livro do seminário. São Paulo: L R Editores, 1983. p. 23. 
No período pós-golpe, a literatura se encontra marcada pela utopia e pelo otimismo refletidos no conteúdo das obras, principalmente envolvendo o funcionamento do poder e as diversas reações do ser que o assistia e participava de toda a realidade de uma ditadura militar. Foi a partir da década de 70 que evoluiu ferozmente $o$ individualismo, a fragmentação do sujeito, que Drummond já mencionava em suas poesias desde a década de 30. Santiago, a respeito da temática da literatura pós-64, diz que "A descoberta assustada e indignada da violência do poder é a principal característica temática da literatura brasileira pós-64". ${ }^{22}$ Juntamente com essa descoberta nascia também uma estética pós-modernista, ou seja, uma literatura voltada para a fragmentação do ser, do tempo e principalmente da identidade.

A forma de narrar de Brandão pode ser atribuída à característica fragmentária da pós-modernidade, que ele bem o faz através do destrinçar do cotidiano, como podemos perceber no trecho a seguir:

Entrei no banheiro, escovei os dentes. Um colírio para os olhos congestionados. A luz do quarto apagada, Adelaide me esperava à porta. Há trinta e dois anos, na hora de dormir, só entra junto comigo, vou até a cama com a mão em seu ombro. Faz bem aos dois esse gesto. Temos a nossa tradição. ${ }^{23}$

Brandão utiliza da fragmentação para construir a personagem, como explica Candido, "na vida, a visão fragmentária é imanente à nossa própria experiência; é uma condição que não estabelecemos, mas a que nos submetemos". ${ }^{24}$

Durante toda a narrativa encontramos momentos em que 0 cotidiano é representado minuciosamente, dissolvido em detalhes que podem desviar a compreensão de todo o texto, marcando assim a sua narrativa com uma das características da pós-modernidade e, além

SANTIAGO, op.cit., p. 16.

NVPN p. 46.

24 CANDIDO, Antonio (org.). A personagem de fiç̧ão. 10 ed. São Paulo: Perspectiva, 2002. A personagem do romance, p. 58.
} 
disso, traz, nesse mesmo excerto, a contradição desse movimento literário, justificando a sua fala e explicitando a preocupação de narrar a sua própria "tradição". O personagem usa o modo de narrar da atualidade e finaliza o parágrafo aludindo a uma prática pautada na conservação de uma tradição, equivalendo assim ao que define Hutcheon, "O pós-modernismo é um fenômeno contraditório, que usa e abusa, instala e depois subverte os próprios conceitos que desafia". ${ }^{25}$

Para sermos mais objetivos, o pós-moderno, além de contraditório, está altamente relacionado e interligado com os aspectos históricos, assim como os de ordem política e social, que retornam ao passado com objetivo de construir uma nova ideologia para o futuro.

O meio lingüístico utilizado para representar as experiências políticas e engendrar o seu ponto de vista acerca de um dado período histórico foi o de adotar a paródia - preferência e construção desde o movimento modernista. Sobre essa forma de conexão entre tradição e ruptura, Santiago afirma ser possível "uma estética de ruptura, da quebra, por uma destruição consciente dos valores do passado". ${ }^{26}$ Havendo na literatura este novo formato para assuntos tais como os políticos, e estando sob de um Ato Institucional (AI-5), o meio mais eficaz para não parar de escrever era certamente a paródia, alternativa utilizada por muitos artistas para abordar no interior de suas produções questões politizadas e/ou para desestruturar bases filosóficas representadas, como aponta Hutcheon. Para ela, a paródia é:

[...] uma forma pós-moderna perfeita, pois paradoxalmente, incorpora e desafia aquilo a que parodia. Ela também obriga a uma reconsideração da idéia de origem ou originalidade, idéia compatível com outros questionamentos pós-modernos sobre os pressupostos do humanismo liberal. ${ }^{27}$

25 HUTCHEON, Linda. Poética do pós-modernismo: história, teoria, fiç̧ão. Trad. Ricardo Cruz. Rio de Janeiro: Imago, 1991. p. 19.

26 SANTIAGO, Silviano. Nas malhas da letra. Ensaios. São Paulo: Companhia das Letras, 1989. p. 94.

27 HUTCHEON, op.cit., p. 28. 
Considerando a idéia de paródia é que voltamos o nosso olhar ao romance NVPN, pela atitude de o narrador incorporar e experienciar a forma de governo vigente durante os anos 70 no Brasil, fazendo alusão principalmente ao passado, caminhando paradoxalmente entre o político e o histórico, o presente, o passado e 0 futuro, fatos possíveis, nesse contexto, através da linguagem parodiada. Lembramos também que no romance a aparência do externo está representada por monumentos do passado, refletindo a sua condição de degradação, reforçando, assim, o que Hutcheon diz sobre esta relação, entre paródia e passado: "A paródia não é a destruição do passado, na verdade, parodiar é sacralizar o passado e questioná-lo ao mesmo tempo. E mais uma vez, esse é o paradoxo pós-moderno". ${ }^{28}$

Assim como a paródia, a intertextualidade pós-moderna tem o seu interesse voltado à redução do que distancia passado e presente, sendo possível reescrever o passado aos seus leitores partindo de um novo contexto histórico. Pensando assim é que encontramos um sentido para o fato de Brandão inserir em seu romance a carta do Rei D. João VI, escrita em 1760, com um decreto-lei contra qualquer tipo de desmatamento da floresta, e muito preocupado com as derrubadas de árvores importantes, problematizando desde já a degradação ecológica que adquire relevância no futuro (tempo presente).

História, política e arte são discursos cujos alicerces foram erguidos sob a égide da pós-modernidade, segundo a leitura que se faz hoje, de maneira a tornar o espaço e o tempo presentes em um único contexto, o qual deve estar sempre e altamente interligado junto à subjetividade de quem narra, desafiando assim o estilhaçamento do ser em cada obra artística. Principalmente em relação ao sujeito pósmoderno, considerado como o ser de subjetividade fragmentada.

Todo este afastamento do ser pode, muitas vezes, estar na reação de uma certa distância mantida entre o narrador e o mundo narrado, principalmente no que está relacionado à construção das personagens e da relação espaço-temporal da narrativa, segundo afirma Villaça (1996): 
A pósmodernidade nos anos 60 reagia contra o alto modernismo, seu funcionalismo, sua despolitização do pós-guerra, contra o abandono da fusão arte/vida orientadora das vanguardas. O pósmoderno dos anos 70 se desdobrou em duas vertentes: a primeira de caráter afirmativo, sem reivindicação crítica; a segunda caracterizada pela perda de confiança e exuberância dos anos $60 .^{29}$

Podemos, através desse pensamento em relação ao tempo, perceber o surgimento da fragmentação, da pluralidade das subjetividades encontradas nos diversos romances escritos nas décadas seguintes à de 70 .

A subjetividade no texto importa tanto quanto o próprio sujeito do texto, principalmente em lugares da narrativa como "a visão do narrador/narradores, a construção das personagens, a organização do espaço/tempo". ${ }^{30}$ Assim percebemos este afastamento do ser, em relação ao sujeito, ao tempo, ao narrador, enfim ao próprio conteúdo do romance quanto à autenticidade da subjetividade do narrador, conforme excerto abaixo:

Não penso mais. Sei. Não há mais o longe, o perto. Não há fuga, nem refúgios, tudo foi devassado. Sinto em mim estranha nostalgia. Antiga, muito antiga. Não dos tempos em que meus bisavós furavam o sertão do Mato Grosso, ou Paraná. Mais para trás. Muito mais. De tempos em que eu ainda não era. ${ }^{31}$

Parece até mesmo um pouco irônico, pois o narrador, que é a personagem protagonista, não sabe precisar a sua identidade e traz à tona um passado tão longínquo para fazer alusão, no presente, à sua origem que ele não consegue nem mesmo imaginar. Percebemos também na voz do narrador a ausência de linearidade no texto.

29 VILlAÇA, Nizia. Paradoxos do pós-moderno: sujeito \& ficção. Rio de Janeiro: Ed. UFRJ, 1996. p. 25.

31 NVPN, p. 87. 
Nesse romance, verificamos muitas vezes um discurso de falência, de desânimo, de fracasso; podemos por vezes atribuir esse fato à História vivenciada em determinado momento, marcada pelas diversas crises políticas e econômicas, principalmente nas décadas de 80 e 90, que atingiram a produção ficcional, "Uma época em que a política tenta reorganizar seus quadros, apagados que foram pelo obscurantismo de 20 anos de ditadura. Época de crise política, econômica, ética, definida por alguns críticos como sendo o império do cinismo, do fisiologismo, da banalização da violência". ${ }^{32}$ Em meio a esses fatores é produzido NVPN.

Dessa forma, a partir da verdadeira arte de narrar, tomemos agora dois importantes elementos que compõem a estética literária. E em se tratando de estética não é possível que esta seja construída apenas com o elemento objetividade, ao contrário, só é possível determiná-la através de um outro elemento, a subjetividade humana. E é essa singularidade que dará origem à particularidade, sendo que a primeira, além de ser originária da subjetividade, é também marcada pelo conhecimento e pela vivência do personagem/narrador. Compreendemos, assim, esses dois elementos como capazes de reproduzir, ou melhor, refletir a realidade, a original visão do autor em um texto literário. Como afirma Lukács: "a objetividade, portanto, não pode ser separada da subjetividade, nem mesmo na mais intensa abstração da análise estética mais geral". ${ }^{33}$

Lukács afirma que é a reflexão artística do real, na essência literária, que torna uma obra totalmente original, não sendo apenas através da reflexão da realidade, mas também através de uma espécie de previsão para um tempo mais promissor, ou seja, cabe ao artista utilizar-se de uma determinada genialidade, do que um dia poderá surgir, do que poderá ser transformado em realidade. 'Prever o futuro' para a arte tem um significado importante, pois o autor não se fixa apenas no ilusório, no imaginário, mas também busca a veracidade para determinados conteúdos previstos. Assim, podemos observar no

\footnotetext{
32 VILLAÇA, op. cit., p. 196.

33 LUKÁCS, Georg. Introdução a uma estética marxista: sobre a categoria da particularidade. Trad. Carlos Nelson Coutinho e Leandro Konder. Rio de Janeiro: Civilização Brasileira, 1978, p. 196.
} 
romance aqui em estudo que Brandão já antecipa a devastadora divisão de classes, seguida da devastação tanto do gênero humano quanto do ambiente natural.

É através da subjetividade que o autor de um texto literário trabalha a representação de sua história, e também de onde se pode compreender a superação da particularidade, já que o universal está para a objetividade, enquanto o singular está para a subjetividade. ${ }^{34} \mathrm{O}$ momento em que um equilíbrio é proporcionado entre ambos, ou seja, a particularidade.

Corroboramos então com Magalhães, ao analisar a arte como sendo a maior forma de expressão da individualidade, da subjetividade do gênero humano, já que:

A arte constitui uma expressão privilegiada da subjetividade; o resultado do reflexo artístico e sua recepção são possibilidades concretas de afirmação da personalidade, pois significam o ato de escolha que um sujeito - o artista, ou o receptor - realiza sobre a forma de tratar os conflitos, que estão diretamente ligados à autoconstrução humana. ${ }^{35}$

Reflexo estético que nos leva a compreender dois importantes e indispensáveis elementos, já citados anteriormente, a subjetividade e o conhecimento de mundo, da história, ou seja, a objetividade. Assim como expressa Jameson (1992), cujo real também faz parte da textura narrativa, sendo que este efeito ocorre através da língua, de maneira intrínseca e imanente, conforme aborda a questão: "O ato literário ou histórico, portanto, sempre mantém uma relação ativa com o real". ${ }^{36}$ É o real que agora faz parte do contexto da textura da narrativa, sendo

34 Schiller (1792) diferencia a subjetividade da objetividade da seguinte forma: "a sensação que é objetiva pode ser chamada pura e simplesmente sensação; a que é subjetiva, porém sentimento"(2003, p.41)

MAGALHÃES, Belmira. Um diálogo entre a realidade $e$ a arte: a estética lukácsiana e Graciliano Ramos. Leitura, Literatura e Sociedade. Maceió, EdufaL, n. 24, p. 53, jul./dez. 1999, 2002.

36 JAMESON, Frederic. $O$ inconsciente político: a narrativa como ato socialmente simbólico. Trad. Valter Lellis Siqueira. São Paulo: Ática, 1992, p. 74 
que esse efeito ocorre através de mecanismos da língua, assim como a história da luta de classes é uma questão trabalhada pelo marxismo como uma luta coletiva, e que constantemente está sendo retomada pelos autores de narrativas, principalmente os contemporâneos.

Sobre a formação dessa batalha, muitas vezes injusta, tomamos o que diz Tonét sobre o surgimento da mesma: "Por sua vez, esta luta, em última análise, tem a ver com o modo de produzir e de repartir a riqueza. Todas as outras dimensões sociais (política, direito, ciência, educação, religião, etc.) serão, de alguma forma, perpassadas por essa luta que se travará entre as classes". ${ }^{37}$

Neste caso, cabe aos críticos analisar três horizontes semânticos: a história política que envolve a narrativa, a sociedade refletida e representada no espaço literário e a história como um todo contextualizado no texto literário.

Alinhamos a nossa idéia à de Jameson a partir do momento que detectamos esses traços no romance, "quando trazemos para a superfície do texto a realidade reprimida e oculta dessa história fundamental, em que a doutrina de um inconsciente político encontra sua função e sua necessidade". ${ }^{38}$

Enquanto isso, Monteiro (1995) atribui às atividades da subjetividade a percepção, o sentimento e o pensamento que envolvem fatores racionais, morais e afetivos; por outro lado, a objetividade compõe-se da sociedade, da cultura, da política, da economia e da história e estes elementos são desenvolvidos na narrativa através da representação do indivíduo, que, para o autor mencionado, "é um singular que sintetiza a si mesmo a unicidade acidental da particularidade e a universalidade histórica da genericidade", ${ }^{39}$ ou seja, o indivíduo construído no texto literário é, a exemplo do homem singular, quem faz parte do mundo ao mesmo tempo que se contrapõe a ele, sendo que este indivíduo está relacionado ao

37 TONÉT, Ivo. Sobre o socialismo. Curitiba: HD Livros, 2002. p. 5.

38 JAMESON, Frederic. $O$ inconsciente político: a narrativa como ato socialmente simbólico. Trad. Valter Lellis Siqueira. São Paulo: Ática, 1992. p. 18.

39 MONTEIRO, Luís Gonzaga Mattos. Neomarxismo: indivíduo e subjetividade. São Paulo: EDUC; Florianópolis: EDUFSC, 1995. p. 114. 
sujeito/personagem/indivíduo que representa a subjetividade da humanidade.

Para tanto, é a partir desse ponto de vista apresentado que acreditamos estar sendo construído o indivíduo, o eu, o ser para uma atuação da subjetividade no campo da arte literária, conforme nos aponta Monteiro, ao falar dessa temática: "a construção do 'Eu' é um processo constante de reciprocidade entre objetividade e subjetividade". ${ }^{40}$ Entretanto, acreditamos que se o eu necessita para a sua construção tanto da objetividade quanto da subjetividade, principalmente em se tratando de textos literários, por conseguinte esse efeito ocorre de acordo com os aspectos da possível realidade que o cerca. Se o mundo à sua volta encontra-se em estado de degradação, logo a sua subjetividade expressará degradação também. Vejamos, aqui, alguns dados específicos da História que contribuíram, conteudísticamente, para a produção literária, principalmente dos anos 70. Tomamos então como fundamento a pesquisa de Pellegrini (1996), ao relacionar arte e política dessa década.

Trata-se de um período marcado pela construção da identidade nacional num momento em que todos vivenciavam a aparente redemocratização, cuja característica básica foi marcada pela 'dinastia' de torturas, massacres e censuras. Essa, através do AI-5, reprimindo toda manifestação de arte que representasse o momento atual à época, e a prisão dos artistas que insistissem em publicar (através da arte) a sua opinião, o seu modo de ver determinadas situações, na verdade censurou todo ato de livre expressão, comprometendo assim a economia, a política, a sociedade e a cultura do país em geral.

Certamente uma das áreas mais afetadas durante todos esses anos de proibição de expressão foi, sem dúvida, a Arte, já que o artista toma o espaço, particularmente o da literatura, para expressar a sua própria vivência. E no romance de Brandão podemos perceber alguns problemas surgidos na ditadura militar sendo objetos de reflexão no espaço literário. Revendo a memória histórica, percebemos que o momento da censura artística funcionou como um espaço de castração

40 MONTEIRO, op.cit., p. 116. 
da liberdade da arte; outros, porém, ridicularizavam a expressão artística afirmando que a censura era tomada como desculpa para a falta de criatividade de seus representantes. Quanto à produtividade, Pellegrini afirma que "a indústria cultural, durante os anos 70, era sustentada pela ideologia do poder autoritário instituído", ${ }^{41}$ momento que propiciou o surgimento de uma cultura de massa, coisificada, de objeto, de produto e dificilmente de arte.

Tendo no próprio ambiente artístico diversas posições acerca do fazer artístico, o homem toma como seu único instrumento a sua experiência de vida, compondo assim a subjetividade, que no momento apresentado já está um tanto comprometida com o militarismo, assegurando, portanto, um certo poder diante da sociedade, pois já que em sua criação reproduz determinados problemas da realidade objetiva, o texto criado pode também provocar efeitos tanto sociais quanto ideológicos. Assim afirma Pellegrini diante de um aspecto realista, mas agora alegórico, instalado na sociedade como também no texto literário, permitindo ao autor levar para o seu campo artístico temas como o caos urbano, a desumanização dos sujeitos, a incomunicabilidade entre pessoas, a individualização e a solidão, inevitáveis para os sujeitos que habitam as paisagens culturais da pós-modernidade, muito presentes e trabalhadas no romance NVPN.

Pellegrini ainda destaca três importantes aspectos que contribuíram para a formação do romance da década de 70 , cuja função de importância se deve à necessidade de revelar ao público as eventuais ocorrências dos ditadores. Destacam-se então a preocupação com o momento histórico, a alegoria e a paródia como os principais recursos para denunciar a violação e o desagregamento da linguagem, sendo o final dos anos 70 marcado pela extinção da censura e pela abertura democrática, propiciando uma certa esperança. Atribui à escrita de Brandão uma relação existente entre esperança e morte, sendo esta a "única saída do labirinto da vida", conforme afirma o crítico. $^{42}$

41 PELLEGRINI, Tânia. Gavetas vazias: ficção e política nos anos 70. São Paulo: EdufScar - Mercado de Letras, 1996. p. 13.

42

Idem., p. 146. 
Essa característica pode ser encontrada na linguagem utilizada por Brandão em seus romances, os quais causam fortes impactos nos leitores, principalmente quando se relacionam aos aspectos políticos representados na formulação interna da obra, como expressa Candido:

Ao mesmo tempo, nos vemos lançados numa ficção sem parâmetros críticos de julgamento. Não se cogita mais de produzir (nem de usar como categorias) a Beleza, a Graça, a Emoção, a Simetria, a Harmonia. O que vale é o Impacto, produzido pela Habilidade ou Força. Não se deseja emocionar nem suscitar a contemplação, mas causar choque no leitor e exercitar a argúcia do crítico, por meio de textos que penetram com vigor mas não se deixam avaliar com facilidade. ${ }^{43}$

Ou seja, assim como os autores estavam assustados com as formas de tortura da ditadura militar, nas obras literárias foi trabalhado um estilo lingüístico-literário que causasse impacto aos leitores, ao retratar, o autor, cenas ou temas relacionados à violência, à prostituição, à marginalidade, à migração, sendo tais obras rotuladas como portadoras de uma espécie de "Realismo Feroz". E este fenômeno só tem aumentado, permitindo-nos, então, interrogar: como podemos "classificar" a literatura das duas últimas décadas até os dias atuais? Não podemos esquecer de que escritor e leitor caminham em um mesmo ritmo acelerado, no ritmo da pós-modernidade, cuja condição obriga o homem dessa época a tornar-se cada vez mais individualista e inserido em uma sociedade também cada vez mais marginalizada, como a apresentada em NVPN, narrativa escrita há mais de vinte anos que continua causando impacto aos seus leitores devido à atualidade dos assuntos retratados.

Construção de processos de exclusão social

Muitos aspectos das sociedades contemporâneas são representados na ficção literária de Ignácio de Loyola Brandão, especificamente em NVPN. Sendo assim, uma das realidades nele manifestadas refere-se à sobrevivência do ser humano inserido em um

43 CANDIDO, Antonio. A educação pela noite e outros ensaios. 3. ed. São Paulo: Ática, 2000. p. 214. 
espaço, em um ambiente e em um meio social degradados. Há, desde o princípio da narrativa, esta necessidade tanto orgânica quanto histórica de sobrevivência no ambiente ecológico: sobreviver ao racionamento contínuo da água, à química utilizada na fabricação dos alimentos factícios, assim como ao apagamento da memória, ao controle do Esquema e a restrição de informações sobre o tempo histórico. Tudo, nessa sociedade representada, se resume a uma única necessidade: sobreviver, como bem focaliza o narrador durante toda a narrativa:

Todos querem apenas sobreviver. Se analisarmos a história, vamos concluir que o nível de vida do povo baixou a zero. Não de todos. Os Que Se Locupletaram estão lá. Aqueles que os serviram se arranjaram. E todo mundo só quis servir. Foram décadas que derrotaram a civilização.

Tempos em que o povo passou a comer menos. A comer pior. Cada vez com menos qualidade. Não chegamos a comer raízes porque elas não existem mais. Esgotamos praticamente tudo. Dependemos das indústrias químicas governamentais ou do que é importado das fechadas reservas multi-internacionais. ${ }^{44}$

Encontramos nesse excerto não apenas a necessidade vital de sobreviver, mas também a causa que levou à privação de alimentos, ao nível de vida tão baixo quanto o das famílias que servem para emocionar, nos dias de hoje, a população através da mídia durante períodos de comemorações de festas populares já enraizadas no imaginário social coletivo, como o Natal, exaltando a miséria em que vivem. No caso do texto literário, o nível estava tão abaixo do normal que nem raízes havia para a alimentação. Há também nesse fragmento uma contradição social, perceptível aos olhos do leitor: a ironia com que ele destaca a diferença de classes retratando aqueles que escaparam da baixa qualidade de vida, denominando-os com as iniciais em caixa alta "Os Que Se Locupletaram". Além da locupletação, um outro meio de sobreviver é participando dos pequenos subornos em troca de fichas para água, alimentação e 
circulação nos distritos determinados, mas sempre condicionados ao que o Esquema dita, aprendendo a conviver com o medo e a desesperança.

O Esquema, muito sagaz, passa o problema adiante, favorecendo os países estrangeiros que possuem recursos para a fabricação de alimentos factícios, reciclagem de urina e a imitação dos cheiros naturais como os de:

Fim de Tarde, Água na Terra Seca, Folha Seca, Folha Podre Úmida, Eucalipto no Fim da Tarde, Coqueiro, Flores, Verduras, Café Torrado, Papel Novo, Algodãozinho, Chá Mate, Bosta de Vaca, Leite Queimado na Chapa, Pão de Forno, Serraria Depois de Cortar Tronco de Cedro, Alfazema, Jasmim, Igreja na Hora da Bênção, Sanitário Limpo de Cinema, Moça que Tomou Banho com Sabonete, Roupa Passada, Jatobá Aberto, Frango Assando, Jaca, Hálito de Criança Após Escovar o Dente, Gás de Escapamento, Quarto Fechado Há Longo Tempo. ${ }^{45}$

Sendo esta uma forma de incomodar a percepção do leitor, tentando nos induzir a valorizar tudo o que está a nossa volta diariamente e que muitas vezes a velocidade do tempo pós-moderno nos impede de atentar aos detalhes que fazem parte da nossa essência, como os odores.

Podemos assim perceber que tanto a degradação do homem quanto a desumanização estão presentes em diversos momentos do romance, aliás, ele já inicia com um exemplo destacando o valor de um ser humano: "Tentaram tudo para eliminar esse cheiro de morte e decomposição que nos agonia continuamente. Será que tentaram? Nada conseguiram. Os caminhões, alegremente pintados de amarelo e verde, despejam mortos, noite e dia. Sabemos, porque tais coisas sempre se sabem. É assim". ${ }^{46}$

Entendemos aqui esses "corpos", que formavam setenta e sete colinas, como o resultado da miséria do país, assim como as vítimas

45 Ibid., p. 91.

46 Ibid., p. 11. 
que foram feitas durante o período da ditadura militar, sendo conduzidos e camuflados por "carros alegremente pintados em amarelo e verde", os quais nos remetem à mísera prostituição enfeitada pelos carros alegóricos dos carnavais de todo o país, assim como a tantas outras contradições que podemos encontrar na história do Brasil. Lembremo-nos também dos grandes massacres ocorridos aos estudantes que protestavam contra a ditadura, os artistas e políticos exilados pela censura, e principalmente a grande massa de migrantes nordestinos que tentavam e tentam até hoje se instalar nas grandes metrópoles.

Uma das formas que o Esquema encontrou para manipular com mais facilidade a população foi através da alteração química nos alimentos por ele fabricados, sendo causa de diversas mutilações, bem como da manipulação ou retenção de técnicas ou métodos que pudessem ampliar a cognição de toda uma população, da seguinte maneira:

- É química que eles misturam. Os aditivos tranquiilizantes. Doses homeopáticas, que vão minando o organismo. Corroendo a vontade, acomodando. Essa calma que existe é conseguida de que modo? Com ameaças, com a presença ostensiva dos Civiltares? Com o aparelhamento de vigilância, fiscalização? Que nada! O Esquema está sossegado porque encontrou um meio infalível. Injeta a tranqüilidade direto no sangue. ${ }^{47}$

Essa tranqüilidade favorece o Esquema diante da necessidade de manipular a população sem nenhuma maior manifestação ou protesto. Um outro fator que firma a dependência ao Esquema diz respeito ao aumento de mutilados. "Os intestinos do povo não funcionaram. Formavam-se bolos alimentares endurecidos, mal digeridos, provocavam cólicas terríveis". ${ }^{48}$ Proveniente também da alimentação, que como já afirmamos, passou a ser totalmente produzida nos laboratórios das indústrias multi-inter devido à devastação das plantações nacionais, causada principalmente pelo racionamento abusivo de água.

\footnotetext{
47 Ibid., p. 122.

48

Ibid., p. 93.
} 
Como vimos dizendo neste capítulo, o Esquema mantém, ou pelo menos finge manter, o controle de toda a situação; vejamos, então, como essa relação é estabelecida, confirmando assim mais uma forma de sobrevivência do poder administrativo e político.

O Esquema é o comando geral de toda a cidade planejada e idealizada no romance; neste caso, ele exerce um poder semelhante ao da função de presidente da república; aqui ele tem por objetivo controlar tudo o que diz respeito à sociedade e todos os que fazem parte dessa coletividade representada na narrativa. Para isso, ele mantém toda uma organização de fiscais, denominados de Civiltares e Militecnos, que, uma vez interpretados à luz de nossa realidade empírica, representariam ou seriam equivalentes às funções das nossas Polícia Civil e Militar.

No caso dos Civiltares, esses são encontrados em toda a parte em vigilância contínua, são conhecidos como bons de pontaria e mágicos, pois apenas com um olhar são capazes de pôr ordem em qualquer situação de desordem, e ainda, "Para cada homem em circulação, existe praticamente um Civiltar ao seu lado", " ${ }^{49}$ ão apenas como garantia de segurança para o cidadão, mas sim para o Esquema, inibindo qualquer movimento suspeito de contradição às regras estabelecidas. São responsáveis principalmente por manter a ordem nas ruas e nos postos apropriados, onde se faz necessária a identificação de cada cidadão para entrar em determinadas ruas, estabelecimentos de trabalho e circulação nos ônibus, praças e bairros. Nesse caso, Souza, o protagonista do romance, concorda com a eficiência dos Civiltares, exaltando o treinamento recebido da seguinte forma: "Parece que são treinados pelos mesmos métodos com que se ensinavam os antigos cães pastores na polícia militar. Ficam condicionados e são uma beleza na eficiência. Por menos que se goste deles, é preciso reconhecer: evitam catástrofes nesta cidade. Pior sem eles" ${ }^{50}$

Os Militecnos sofrem mais do que condicionamentos sofrem metamorfose; alguns optaram por este serviço ao Esquema como um

\footnotetext{
49 Ibid., p. 20.

50 Ibid., p. 21.
} 
meio de sobreviver ao tempo e às precárias condições de vida proporcionadas até então.

Ficou demonstrado pelos cientistas. Foi mais uma das razões que os tornaram marginalizados. Provou-se que os Militecnos sofreram metamorfose em seu organismo. O cérebro ficou afetado. Perdeu parte da memória. As emoções foram eliminadas. Tornaram-se serenamente calculistas. $^{51}$

Essa metamorfose de que falamos está relacionada principalmente aos seus sentimentos que foram anulados. Sem as faculdades sentimentais, sem memória, sendo utilizados apenas para assegurar o controle mantido pelo Esquema sobre a população, que a cada dia caminha, na lentidão, até a morte, formam, assim, uma legião.

Os Militecnos e os Civiltares nos fazem lembrar dos soldados e policiais que agrediram e torturaram homens, mulheres e crianças de todos os estratos sociais durante o período da ditadura militar imposta à sociedade brasileira a partir de 1964; recordamos também as diversas formas de tortura, como a geladeira, o afogamento, o choque elétrico, o pau-de-arara, a cadeira do dragão, através de insetos e animais, de produtos químicos, provocando lesões físicas, entre outras maneiras de agressão, como bem abordado em Brasil: nunca mais (1985). Quando nos voltamos para o tempo presente, podemos verificar a continuidade de tanta agressão nas ruas, nas escolas, nas carceragens, nos morros e favelas, no meio doméstico; o desrespeito humano continua expresso na sociedade brasileira. Concordamos então com os estudos de Tonet, quando afirma que:

O momento atual da história da humanidade nos indica outra coisa. Que não é apenas da natureza do capital produzir desigualdades sociais. É também da natureza da sua reprodução, a partir de certo momento, produzir tanto mais desigualdades sociais quanto maior for o seu desenvolvimento. É o que estamos vendo hoje. De um lado, extraordinário desenvolvimento da riqueza; de 
outro lado, intensificação nunca vista das desigualdades e dos problemas sociais (miséria, fome, violência, drogas, guerras, exclusão social, degradação das condições de vida de milhões de pessoas, devastação da natureza, etc.). ${ }^{52}$

Hoje há um outro tipo de movimento que direciona o comportamento da população, o narcotráfico. É grande a quantidade de jovens que a cada dia compromete a sua vida, aumentando assim os conflitos entre as classes sociais, que estão espalhados por todo o país. No romance NVPN, essa realidade de diferença de classes é representada pela organização do Esquema, principalmente quanto ao espaço a que cada morador deve ter acesso. Foi criada a área de Circulação, Boca de Distrito com ficha de autorização, tudo pela ordem, porque:

Tem gente demais nesta cidade. Um dia, os Departamentos Circulantes verificaram que ninguém podia se mexer. Estavam todos aglomerados, apertados, comprimidos. Praticamente imóveis. Os empregos ficaram vazios, a maioria não conseguiu chegar. A solução foi criar as Áreas de Circulação. ${ }^{53}$

De certa forma, Brandão busca a ironia ou a paródia para expressar a realidade do sistema de governo mantido durante a ditadura militar, como é o caso dessa fiscalização através de militecnos e civiltares, assim como a criação dos serviços "[...] SOI número 1 e SOI número 2. O primeiro era o Sistema Organizado de Incompetência e o segundo, o Serviço Organizado de Ineficiência", ${ }^{54}$ cuja recordação nos leva ao SNI (Sistema Nacional de Informação), criado, na verdade, para espionar a vida dos cidadãos. Esse serviço estava presente por todas as partes, assegurando a segurança e reputação do governo, enquanto no romance em questão a finalidade deste serviço é a de punir aquele que se mostre eficiente em alguma atividade, deixando claro toda a ineficiência de que fosse capaz, e só

52 ARNS, Dom Paulo Evaristo. Brasil: nunca mais. 7 ed. Petrópolis: Vozes, 1985. p. 8.

53 NVPN p. 39.

54 Ibid., p. 59. 
VERÁS PAISS NENHUM

eri⿱⺈ digno de atingir «aproximação ao SOI quem mostrasse alta habilidade em estabelecer relações amistosas com a corrupção.

Estudantes e professores sofreram com a criação do SNI, pois esse sistema foi elaborado para fiscalizar a todos, e nas universidades o clima era cada vez mais de desconfiança, afinal ninguém podia fazer qualquer tipo de comentário sobre o governo, já que o fiscal denunciador poderia ser a pessoa ao lado; além disso, havia o sistema de vigilância por câmeras, retransmissores, ou seja, todos viviam sob o autoritarismo do governo. Essa situação é vivenciada pelo personagem Souza, do romance analisado:

Quando eu dava aulas, os estudantes perguntavam sobre tais tempos. Eram alunos que as escolas reputavam incômodos e terminavam afastados dos cursos. A direção ouvia as gravações das aulas e me chamava para que eu informasse quem tinha me interrogado. Denunciasse. ${ }^{55}$

[...] A direção queria saber por quê. Que tipo de coisa eu andava dizendo fora das classes. Mandaram me seguir, plantonaram minha casa, grampearam meu telefone. ${ }^{56}$

Essa era uma das formas utilizadas pelo Esquema para afastar a população das notícias, mantendo-a desinformada e assim cada vez mais confiante nos planos e nas estratégias do autoritarismo, do Grande Irmão, como diz Orwell. Essa atitude de fiscalização das informações vai gerar certo rompimento, um apagamento da história na memória da população, e assim ter o país nas mãos de estrangeiros, tanto física como culturalmente. O verdadeiro objetivo era apagar a memória do povo, como se pode concluir a partir do excerto abaixo:

Esses cientistas especializados na mente do homem brasileiro surgiram depois do boom de brasilianistas. Toda a história brasileira foi revista e reescrita por esses amáveis professores norte-americanos. Em seguida apareceram os biólogos, os anatomistas, os pesquisadores da mente. ${ }^{57}$

$\begin{array}{ll}55 & \text { Ibid., p. } 22 . \\ 56 & \text { Ibid., p. } 23 . \\ 57 & \text { Ibid., p. } 33 .\end{array}$ 
[...]Aqueles homens pretenderam eliminar a história, tentando apagar o futuro. Para que não se lembrem como novos Átilas, os devastadores. Se acreditaram tão poderosos que julgaram poder cancelar a memória do povo. ${ }^{58}$

Eliminar a memória coletiva, essa era a estratégia do Esquema. No entanto, Souza contradiz essa evidência ao viver de suas recordações, não se contentando com as informações dos jornais e das rádios manipuladas e organizadas pelo Esquema, que começava a se mostrar um verdadeiro caos, tanto interior quanto exteriormente. Interiormente, relacionamos esse à ausência da memória que Souza tanto ressalta no transcorrer do seu percurso através da destruição, do não-realizado, do sonhado, como pode ser observado no fragmento que se segue:

Dos anos setenta em diante, fomos conduzidos dentro de indefinições. Rodeados por coordenadas paradoxais. Sistemas duros, ares democráticos. Repressões justificadas e justificativas aceitas. Democracias em clima de ditadura. Regimes amorfos a respeito dos quais não sabíamos avaliar. ${ }^{59}$

A vida de todos era conduzida para o indefinível, para o vazio, para aquilo que não fazia parte da verdade de um povo em um dado momento histórico, e da situação de degradação que se instalava através da forma de governo da alta ditadura, estilhaçando a identidade do sujeito, representado através de Souza - esse ponto será retomado no terceiro capítulo. O interessante de se observar é que no período da execução da lei de censura contra toda e qualquer manifestação artística que estivesse direcionada ao governo, a cultura, mais especificamente a literatura, sofreu uma brusca parada no tempo; não que estivessem faltando escritores, mas passou-se a produzir, no Brasil, uma linguagem moldada pela forma de governo da época.

O narrador evidencia, no romance, um povo sem cultura, desinformado, desatualizado da real situação do seu próprio território, a ponto de aceitar a venda do país para outros continentes, a destruição das

58 Ibid., p. 104.

59 Ibid., p. 66. 
suas reservas florestais e, principalmente, das fontes de água, levando a população a uma imigração no seu próprio território nacional. Conduzidos por um novo conceito de nação, associado à globalização do mundo, chegando até mesmo a cair no absurdo de manter uma colonização escravocrata, que, aliás, existiu desde a descoberta do país. "-Tio, os conceitos de nação mudaram. O que vale agora é o internacionalismo. A multiplicidade. Aqui é um pedacinho. Você soma com os pedacinhos que temos aí fora". "- Não é colonização, tio, é diferente. São reservas multi-internacionais. O mundo se globaliza". ${ }^{60}$

Globalização, neste romance, se tornou a saída para manter o país. Diante de tantas dívidas, não havia recursos nem mesmo para manter o índice mínimo da economia. A importação se tornou constante, no entanto com uma diferença: importa-se de dentro do mesmo país: "[...] Importamos de nós mesmos. Mandamos buscar ali em cima, onde antes era o norte do Mato Grosso, o Maranhão, o Pará". ${ }^{61}$ Dessa forma, o país de NVPN resumia-se a uma cidade, São Paulo, onde o Esquema mais atuava; a cidade começava a se tornar mais congestionada a cada dia, pois as famílias sobreviventes das outras regiões migravam para lá. Para dar vez às Multinter que se desenvolviam cada vez mais nesse território, que era nacional - uma vez que estava instalada em solo brasileiro - e estrangeiro, porque oriundo de uma outra cultura, transplantada, com propósitos específicos, para a sociedade representada em NVPN. A sociedade representada neste romance problematiza, com esse caso, a noção de território, pois esse, nos chamados processos de globalização, é redimensionado a ponto de tal conceito perder sua significação primeira em nome de novas formas de relacionamentos geofísicos.

- Há uns dois anos. Chegava gente de todos os lados. Famílias inteiras expulsas das Multinter. Os estrangeiros traziam sua própria gente. Quando utilizavam brasileiros era para serviços braçais, servis. Faziam conosco a mesma coisa que fizemos com os negros e índios, quinhentos anos atrás. ${ }^{62}$

\footnotetext{
60 Ibid., p. 78.

61 Ibid., p. 79.

62 İbid., p. 167.
} 
Muito se tem (re)pensado sobre territorialidade, principalmente com o desenvolvimento exacerbado da globalização, especificamente no que diz respeito à área tecnológica. Conforme Achugar, esse processo de globalização vem mudando o direcionamento de nação enquanto lugar, território, sendo então visto como um processo de homogeneização e consolidação na América entre os povos e as variedades de cultura, cujo princípio se deu com o colonialismo, e hoje ninguém sabe aonde vai chegar. Assim como o próprio autor questiona: “ ¿Em qué medida los sujeitos sociales - a nível nacional o simplesmente a nível de comunidades reducidas - han sido movilizados por la globalización o simplesmente por la transformación tecnológica?, ${ }^{63}$ entendendo, dessa forma, que não há limites para a transformação das culturas devido à devastadora era da tecnologia, e ressaltando que essa se faz presente no romance como solução para suprir a destruição dos elementos naturais de que a própria tecnologia foi meio para que se chegasse ao ponto culminante da defasagem do sistema ecológico.

Entretanto, sobreviver ao Esquema exige muito mais do que ficar omisso a ele; requer uma posição centrada em si mesmo para possibilitar alguma tentativa de mudança contradizendo-o, permanecendo em uma posição, digamos, tendo uma postura deslizante diante do Esquema, ora seguidor das suas regras, ora verificando possíveis mudanças, através da memória. No entanto, Souza se torna o pivô da narrativa, mas como um único ser não é capaz de realizar tais prodígios, ele falha nas suas ingênuas atitudes, embora leve o leitor a enxergar a realidade de maneira mais crítica, observando o passado para assim construir um futuro.

Brandão representa, em seu romance, diversos momentos da nossa história. Remete-nos ao descobrimento do Brasil, aos anos de escuridão do militarismo no poder, assim como também à organização de um novo tempo: a pós-modernidade. Em seu romance encontramos uma espécie de desabafo, não só dele, mas de uma geração inteira, que não está tão distante do momento atual. Utilizando uma linguagem

63 ACHUGAR, Hugo. Repensando la heterogeneidad latinoamericana (a propósito de lugares, paisajes y territórios).in: MABEL Moraña (dir.) Revista Iberoamericana, Pittsburgh, ns. 176 - 177, jul.-dic., 1996. p. 847. 
que o próprio narrador reconhece ser de ficção científica, e uma forma exaustiva de narrar, ele vai aos poucos denunciando e revelando a história, partindo do olhar de quem esteve na oposição.

\section{Referências}

ACHUGAR, Hugo. Repensando la heterogeneidad latinoamericana (a propósito de lugares, paisajes y territórios).in: MABEL Moraña (dir.) Revista Iberoamericana, Pittsburgh, ns. 176 - 177, jul.-dic., 1996.

ARNS, Dom Paulo Evaristo. Brasil: nunca mais. 7 ed. Petrópolis: Vozes, 1985.

BARBOSA, João Alexandre. Modernidade do romance. In. FILHO, Domício Proença. (Org). O livro do seminário. São Paulo: L R Editores, 1983. p. 19-42.

BRANDÃO, Ignácio de Loyola. Cadernos de Literatura Brasileira. Instituto Moreira Salles. N. 11, Junho, 2001.

BRANDÃO, Ignácio de Loyola.. Não verás país nenhum. 23 ed. São Paulo: Global, 2000.

CANDIDO, Antonio. Literatura e sociedade: estudos de teoria e história literária. São Paulo: Editora Nacional, 1965.

CANDIDO, Antonio. A educação pela noite e outros ensaios. 3 ed. São Paulo: Ática, 2000.

CANDIDO, Antonio (org.). A personagem de ficção. 10. ed. São Paulo: Perspectiva, 2002. A personagem do romance.

HOHLFELDT, Antonio. O verbo violentou o muro. Ficção científica nos anos 70: o caso Ignácio de Loyola Brandão. Cadernos de Literatura Brasileira. Instituto Moreira Salles. n. 11, junho, 2001. p.109-135.

HUtCHEON, Linda. Poética do pós-modernismo: história, teoria, ficção. Trad. Ricardo Cruz. Rio de Janeiro: Imago, 1991.

JAMESON, Frederic. $O$ inconsciente político: a narrativa como ato socialmente simbólico. Trad. Valter Lellis Siqueira. São Paulo: Ática, 1992. 
LUKÁCS, Georg. Introdução a uma estética marxista: sobre a categoria da particularidade. Trad. Carlos Nelson Coutinho e Leandro Konder. Rio de Janeiro: Civilização Brasileira, 1978.

MAGALHÃES, Belmira. História da representação literária: um caminho percorrido. Revista Brasileira de Literatura Comparada. Maceió, n. 6, UFAL, 2002.

MAGALHÃES, Belmira. Um diálogo entre a realidade $e$ a arte: $a$ estética lukácsiana e Graciliano Ramos. Leitura, Literatura e Sociedade. Maceió, n. 24, jul.-dez. 1999, EDUFAL, 2002.

MONTEIRO, Luís Gonzaga Mattos. Neomarxismo: indivíduo $e$ subjetividade. São Paulo: EDUC; Florianópolis: EdufSC, 1995.

NUNES, Benedito. $O$ tempo na narrativa. 2. ed. São Paulo: Ática, 2000.

PELLEGRINI, Tânia. Gavetas vazias: ficção e política nos anos 70 . São Paulo: EDUFSCAR - Mercado de Letras, 1996.

POLZONOFF Jr, Paulo. Pós-modernismo: nascimento e morte. Continente Multicultural, Pernambuco, ano IV, n.42, p. 80-83, jun. 2004.

SANTIAGO, Silviano. Nas malhas da letra. Ensaios. São Paulo: Companhia das Letras, 1989.

SCHILLER, Fredrich. Fragmentos das preleções sobre a estética do semestre de inverno de 1792-93. Recolhidos por Christian Friedrich Michaelis. Trad. Ricardo Barbosa. Belo horizonte: UFMG, 2003.

SILVERMAN, Malcolm. Moderna ficção brasileira. Trad. João Guilherme Linke. Ensaios. São Paulo: Civilização Brasileira, 1982.

TONÉT, Ivo. Sobre o socialismo. Curitiba: HD Livros, 2002.

VILLAÇA, Nizia. Paradoxos do pós-moderno: sujeito \& ficção. Rio de Janeiro: Ed. UFRJ,1996. 